\title{
A phylogenetic analysis of Brycon and Henochilus (Characiformes, Characidae, Bryconinae) based on the mitochondrial gene 16S rRNA
}

\author{
Alexandre Wagner Silva Hilsdorf ${ }^{1}$, Claudio Oliveira ${ }^{2}$, Flávio César Thadeo de Lima ${ }^{3}$ \\ and Cristianne Kayoko Matsumoto ${ }^{1}$ \\ ${ }^{1}$ Laboratório de Genética de Peixes e Aqüicultura, Núcleo Integrado de Biotecnologia, \\ Universidade de Mogi das Cruzes, Mogi das Cruzes, SP, Brazil. \\ ${ }^{2}$ Departamento de Morfologia, Instituto de Biociências, Universidade Estadual Paulista, Botucatu, \\ SP, Brazil. \\ ${ }^{3}$ Museu de Zoologia, Universidade de São Paulo, São Paulo, SP, Brazil.
}

\begin{abstract}
The genus Brycon, the largest subunit of the Bryconinae, has 42 valid species distributed from southern Mexico to the La Plata River in Argentina. Henochilus is a monotypic genus, comprising a single species $(H$. wheatlandii) found in the upper Rio Doce basin. In the present study, partial sequences of the mitochondrial gene $16 S$ were obtained for fifteen species of Brycon and for Henochilus wheatlandii. The results showed that the genus Brycon is paraphyletic, since Henochilus is the sister-group of $B$. ferox and $B$. insignis. The most basal species analyzed were the trans-Andean species B. henni, B. petrosus, and B. chagrensis.
\end{abstract}

Key words: phylogeny, molecular systematics, mitochondrial DNA, fish evolution, systematic.

Received: October 25, 2006; Accepted: July 10, 2007.

The subfamily Bryconinae includes 74 nominal species out of which 44 are currently considered as valid (Lima, 2003; 2004). The genus Brycon is the largest subunit of the Bryconinae, consisting of 42 valid species ( $\mathrm{Li}$ ma, 2003; 2004). Géry (1977) and Géry and de Rham (1981) delimited the subfamily as comprising the genera Brycon, Catabasis, Chalceus, Chilobrycon, Salminus, and Triportheus. In a more recent account, Lima (2003), partly based on Zanata (2000), restricted the subfamily Bryconinae to the genera Brycon, Chilobrycon, and Henochilus. A morphological and molecular study of Henochilus wheatlandii reinforced the hypothesis that this genus belongs to the subfamily Bryconinae (Castro et al., 2004).

Species of Brycon are widely distributed from southern Mexico to the La Plata River in Argentina. They are particularly diverse in Panama, and in the trans-Andean rivers of Colombia and Ecuador. They also occur in the cis-Andean South America river basins as well as in the Atlantic and Caribbean coastal river drainages (Lima, 2003). Fishes of the genus Brycon are important for human consumption and sport fishing. Different species are commer-

Send correspondence to Alexandre Wagner Silva Hilsdorf. Laboratório de Genética de Peixes e Aqüicultura, Núcleo Integrado de Biotecnologia, Universidade de Mogi das Cruzes, Av. Dr. Cândido Xavier de Almeida Souza 200, 08780-911 Mogi das Cruzes, SP, Brazil. E-mail: wagner@umc.br. cially caught (Carosfeld et al., 2003) or raised in fish breeding programs (Wasko et al., 2004). Species of Brycon are very sensitive to anthropogenic disturbances and several species are now considered as endangered in Brazil (Rosa and Lima, 2005). The genus Henochilus is monotypic and its single species, $H$. whetlandii, is currently known only from the upper Rio Doce Basin, a coastal drainage in the state of Minas Gerais, Brazil (Castro et al., 2004).

The mitochondrial large subunit (16S) rRNA gene (16S rRNA) has been extensively used for the study of phylogenetic relationships, even among closely related taxa (Shimabukuro-Dias et al., 2004). In the present study, a first attempt to infer a molecular-based phylogeny of the genera Brycon and Henochilus based on partial 16S rRNA mitochondrial sequences was conducted with the objectives to test the monophyly of Brycon and Bryconinae (sensu Lima, 2003), the relationship between Brycon and Henochilus and the relationship among trans- and cisAndean species of Brycon.

DNA sequences of thirteen species of Brycon representing trans- and cis-Andean basins were examined (Table 1). Ten additional sequences determined by Castro et al. (2004) and Calcagnoto et al. (2005) were obtained from GenBank (Table 1). Based on the study of Calcagnoto et al. (2005) two species of the genus Chalceus were selected as outgroup. 
Table 1 - Specimens sequenced in the present study and data obtained from GenBank. IAvHP = Colección de Peces dulceacuícolas del Instituto Alexander von Humboldt, Boyaca, Colombia; LBP = Laboratório de Biologia e Genética de Peixes, Instituto de Biociências, Universidade Estadual Paulista, Botucatu, São Paulo, Brazil; MZUSP = Museu de Zoologia, Universidade de São Paulo, São Paulo, Brazil; AMNH = American Museum of Natural History, USA.

\begin{tabular}{|c|c|c|c|}
\hline Species & Locality & Collection number & Genbank \\
\hline Brycon amazonicus & Tomo River, Colombia & IAvHP 4490 & DQ530607 \\
\hline Brycon aff. atrocaudatus & Santa River, Macate, Ancash, Peru & LBP 1356 & DQ530602 \\
\hline Brycon chagrensis & Río Llano Sucio, Santa Rita Arriba, Colón, Panama & LBP 2749 & DQ530614 \\
\hline Brycon ferox & Mucuri River, Espírito Santo, Brazil & Not preserved & DQ530609 \\
\hline Brycon henni & Santacruz River, Santander, Colombia & IAvHP 4355 & DQ530612 \\
\hline Brycon insignis & Paraíba do Sul River, Caçapava, São Paulo, Brazil & Not preserved & DQ530610 \\
\hline Brycon moorei & Rancheria River, Guajira, Colombia & IAvHP 40 & DQ530608 \\
\hline Brycon nattereri & Itaúna River, Baenpedi, Minas Gerais, Brazil & Not preserved & DQ530611 \\
\hline Brycon opalinus & Paraibuna River, São Luiz do Paraitinga, São Paulo, Brazil & Not preserved & DQ530603 \\
\hline Brycon orbignyanus & Paraná River, São Paulo, Brazil & Not preserved & DQ530606 \\
\hline Brycon orthotaenia & São Francisco River, Bahia, Brazil & Not preserved & DQ530605 \\
\hline Brycon pesu & Aripuanã River, Mato Grosso, Brazil & MZUSP uncat. & DQ530604 \\
\hline Brycon petrosus & Río Llano Sucio, Santa Rita Arriba, Colón, Panama & LBP 2750 & DQ530613 \\
\hline Acestrorhynchus sp. & Unavailable & Not cited & AY787956 \\
\hline Astyanax bimaculatus & Unavailable & Not cited & AY787955 \\
\hline Brycon hilarii & Unavailable & Not cited & AY787976 \\
\hline Bryconops sp. & Unavailable & Not cited & AY787985 \\
\hline Chalceus erythrurus & Unavailable & AMNH233413 & AY787990 \\
\hline Chalceus macrolepidotus & Unavailable & AMNH233404 & AY787999 \\
\hline Exodon paradoxus & Unavailable & AMNH233426 & AY788013 \\
\hline Hemibrycon beni & Unavailable & AMNH233328 & AY788020 \\
\hline Henochilus wheatlandii & $\begin{array}{l}\text { Rio Santo Antônio, São Sebastião do Rio Preto, } \\
\text { Minas Gerais, Brazil }\end{array}$ & MZUSP73105 & AY170135 \\
\hline Triportheus angulatus & Unavailable & AMNH233403 & AY788082 \\
\hline
\end{tabular}

Tissues were obtained from adipose fin biopsy and stored in $95 \%$ ethanol until their use. One to three individuals of each species were used for DNA extraction, amplification and sequencing. Total DNA from ethanol-preserved tissues was extracted in accordance with the protocol described by Taggart et al. (1992) modified by using smaller amounts of EDTA in the extraction buffer $(0.1 \mathrm{M} \mathrm{NaCl}$, $0,05 \mathrm{M}$ Tris- $\mathrm{HCl}$ e $0.01 \mathrm{M}$ EDTA, $\mathrm{pH}$ 8.0). PCR amplifications of partial 16S rRNA were performed with primers 16Sa-L and 16Sb-H (Palumbi et al., 1991). Symmetric amplifications were carried out in $50 \mu \mathrm{L}$ reactions containing $2.0 \mathrm{mM} \mathrm{MgCl} 2,0.25 \mathrm{mM}$ each dNTP, $0.7 \mu \mathrm{M}$ of each primer, Taq polymerase ( 2 units) and $200 \mathrm{ng}$ of DNA template. Amplification reactions were performed with a regime of $94{ }^{\circ} \mathrm{C}$ for $3 \mathrm{~min}$ and then 35 cycles of $60 \mathrm{~s}$ at $94{ }^{\circ} \mathrm{C}$ denaturation, $60 \mathrm{~s}$ at $51^{\circ} \mathrm{C}$ annealing, and $90 \mathrm{~s}$ at $72{ }^{\circ} \mathrm{C}$ extension, followed by a final $5 \mathrm{~min}$ at $72{ }^{\circ} \mathrm{C}$. PCR products were checked in $1 \%$ agarose gels and purified using the E.Z.N.A. ${ }^{\circledR}$ System (Omega Bio-Tek, Inc). The purified PCR products were sequenced with the BigDye Terminator Cycle Sequencing kit (Applied Biosystems) according to the protocols provided by the manufacturer. Electrophoresis of the purified samples was performed in an ABI Prism 3100 DNA Sequencer (Applied Biosystems).

The sequences were aligned with the software Clustal W (Thompson et al., 1994), as implemented in the program DAMBE (Xia and Xie, 2001), with the following multiple alignment options: DNA transitions weight equal to 0.5 , IUB DNA weight matrix, option "delay divergent sequences" equal to 30 , three gap open penalties $(5,10$, and 15$)$, and three gap extension penalties $(0.1,1.0$, and 2.0). Nucleotide saturation was analyzed by plotting the number of observed transitions ( $\mathrm{Ti}$ ) relative to that of transversions (Tv) against genetic distance values (Kimura, 1980). Genetic distance analyses were based on a hierarchical hypothesis test of alternative models implemented with Modeltest 3.7 (Posada and Crandall, 1998).

Maximum-parsimony (MP) based phylogenetic analyses were performed using the software PAUP* beta version 4.0b10 (Swofford, 2002) with heuristic searches using random addition of sequences and the tree bisection and reconnection (TBR) algorithm. In all analyses, the character-state optimization method employed was the acceler- 
ated transformation (ACCTRAN). Parsimony trees were generated using 1:1 and 1:2 Ti/Tv ratios, considering gaps either as missing data or as a fifth base. Bootstrap resampling (Felsenstein, 1985) was applied to assess support for individual nodes using 1000 replicates with 100000 random additions and TBR branch swapping. Decay indexes (Bremer, 1988) were calculated with SEPAL (Salisbury, 2001).

Maximum-likelihood (ML) based phylogenetic relationships were estimated using the software PAUP* beta version 4.0b10 (Swofford, 2002). The GTR model (Rodríguez et al., 1990), incorporating rate variation (G) and PINVAR with four G-distributed rate classes (Swofford $e t$ al., 1996), was utilized for all likelihood analyses based on a hierarchical hypothesis test of alternative models implemented with Modeltest 3.7 (Posada and Crandall, 1998). $\mathrm{The} \mathrm{Ti} / \mathrm{Tv}$ ratio, gamma shape parameter, and proportion of non-variant sites were estimated by maximum likelihood from a maximum parsimony tree. Gaps were considered as missing data. Bootstrap resampling was applied to assess support for individual nodes using 100 replicates with 10000 random additions and TBR branch swapping.

Bayesian analyses using the Markov chain Monte Carlo technique were performed by MrBayes 3.0b4 (Huelsenbeck and Ronquist, 2001). We used the GTR + G + I model, and initiated an analysis from a random starting tree run for one million generations. The log-likelihood scores were found to stabilize after 10,000 generations. Therefore, we discarded the initial 10,000 generation trees and sampled one out of every 100 generations from the remaining 0.99 million generations ( 9900 trees) to calculate posterior probabilities for each branch of the Bayesian tree.

The combined sequence data of the 23 taxa resulted in 490 characters, out of which 302 were constant and 108 were parsimony-informative. The transitions/transversions $(\mathrm{Ti} / \mathrm{Tv})$ ratio observed was 1.8 . The results from the analysis of plotting transitions and transversions against genetic distance do not suggest the occurrence of nucleotide saturation (Figure 1).

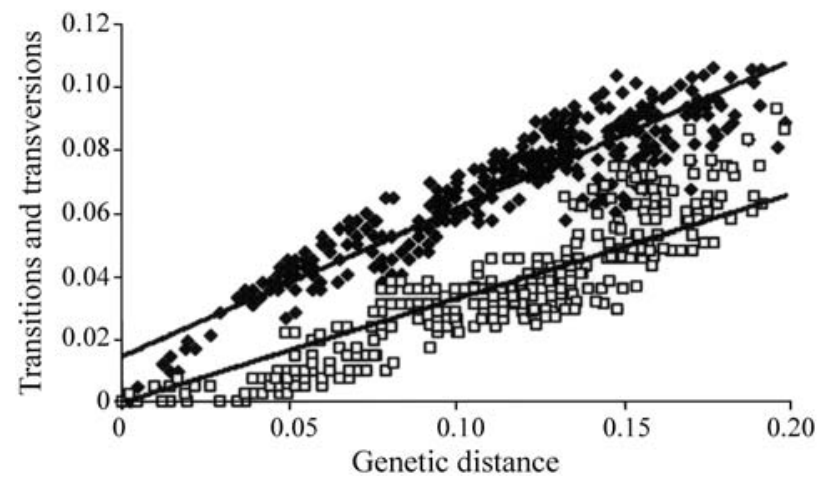

Figure 1 - Frequency of observed transitions and transversions versus genetic distance (Kimura, 1980) of the 16S rRNA gene. Transitions are black squares, transversions are open squares.
Eight MP heuristic searches were conducted employing all data or excluding 23 characters belonging to one segment ( 8 base pairs) without a direct alignment solution, including or excluding gaps, and considering the Ti/Tv ratios of $1: 1$ or $1: 1.8$. The resultant phylogenies were largely congruent. The best resolved consensus MP tree obtained from the analysis of 1000 bootstrap replicates including all data and considering gaps as a fifth base and the Ti/Tv ratio of 1:1 is presented in Figure 2a. For this tree the results obtained were: tree length $(\mathrm{TL})=478$, consistency index $(\mathrm{CI})=0.5774$, and retention index $(\mathrm{RI})=0.5992$. Bayesian analysis of all the trees sampled at stationarity was -2735.129. The consensus Bayesian tree is shown in Figure $2 \mathrm{~b}$. ML analyses resulted in a consensus phylogeny very similar with those obtained in the Bayesian analyses (-Ln likelihood $=1592.036$ ). The values higher than or equal to $50 \%$ found in the 100 bootstrap replicates of ML analysis are shown in Figure 2b.

The phylogenetic relationships within Characidae are still poorly known, and even monophyly is uncertain (Weitzman and Malabarba, 1998). A molecular phylogenetic analysis conducted by Calcagnoto et al. (2005) recovered the family Characidae as a characiform clade, though excluding the subfamily Serrasalminae (sensu Jégu, 2003). In the cited molecular study, fishes of the genus Chalceus were found to be the sister-group of all remaining species of characids. This latter finding, however, is contradicted on morphological grounds, since Zanata and Vari (2005) concluded that Chalceus is the basal-most member of Alestidae, a family of African characiforms. The remaining characid clades found in the analysis conducted by Calcagnoto et al. (2005) are: 1 - Acestrorhynchus and Bryconops; 2- Brycon and Salminus; 3- Triportheus; 4Bryconamericus, Knodus, Creagrutus, Hemibrycon, Gephyrocharax, and Mimagoniates; 5- Aphyocheirodon, Cheirodon, Cheirodontops, Prodontocharax, Exodon, and Roeboides; and 6- Astyanax, Astyanacinus, Inpaichthys, Moenkhausia, Hemigrammus, and Hyphessobrycon. Unfortunately, although we lack published detailed morphological phylogenies with which Calcagnoto et al. (2005) results could be compared, it is worthy to note the apparent congruence of such results with current views on characid phylogeny based on morphology. For instance, the basalmost clades within Characidae, Chalceus excepted, are Acestrorhynchus and Bryconops, Brycon and Salminus, and Triportheus, all taxa (with the exception of Acestrorhynchus) supposed to be basal on morphological grounds (see e.g., Malabarba and Weitzman 2003). The clade formed by Brycon and Salminus suggested the non-monophyly of Brycon, since Salminus was recovered as the sister taxon of $B$. hilarii, with an unidentified species of Brycon as the sister taxon of the latter clade (Calcagnoto et al., 2005). Species of the genus Salminus were not included in the present analysis since morphological studies suggest that this genus has several plesiomorphic charac- 
a)

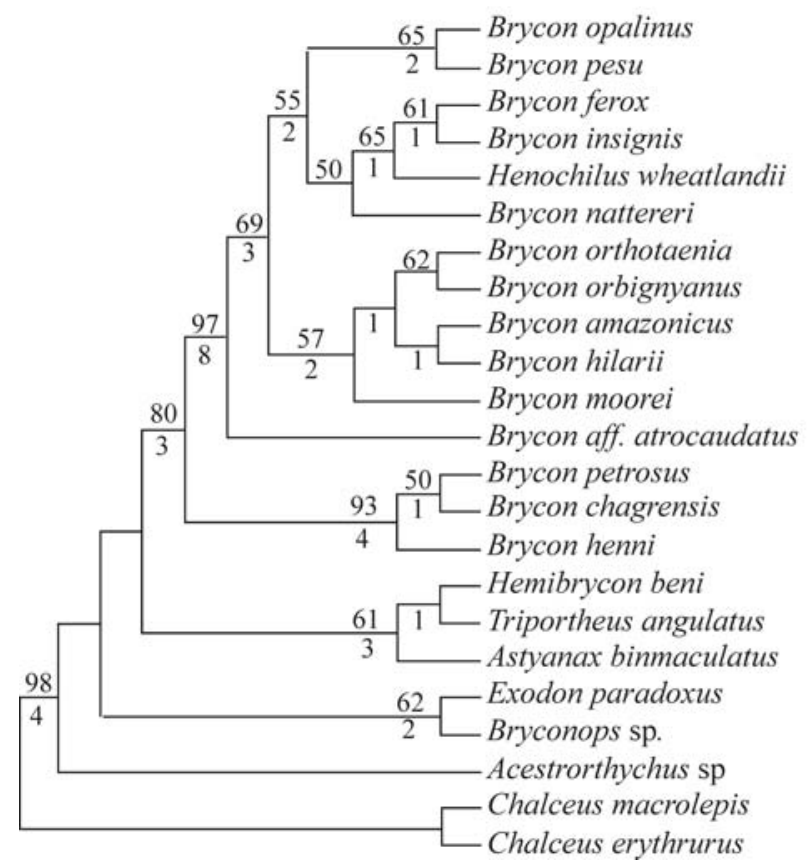

b)

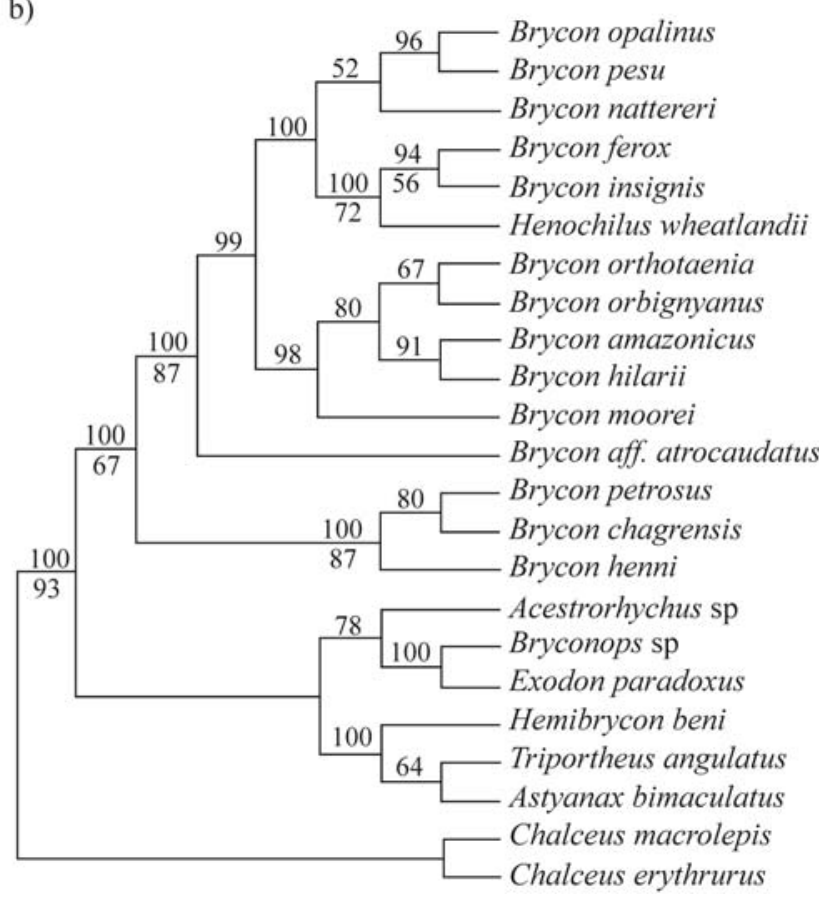

Figure 2 - Phylogenetic analyses of Brycon and Henochilus with Maximum Parsimony (MP) and Bayesian analysis (MB). (a) Consensus MP tree produced when all data were included, gaps were treated as a fifth base and the Ti/Tv ratio of $1: 1(\mathrm{TL}=478, \mathrm{CI}=0.5774, \mathrm{RI}=0.5992)$. Numbers above branches are bootstrap values based on 1000 replicates. Values below $50 \%$ are not shown. Numbers below branches represent Bremer support index values. (b) Consensus MB tree. Numbers above nodes are posterior probabilities recovered by the Bayesian analysis. Numbers below branches are bootstrap values based on 100 replicates in maximum likelihood analyses. Values below $50 \%$ are not shown.

ters conveying a basal position within Characidae (Lima, 2006).

The results of the four methods employed to reconstruct the phylogeny of Bryconinae were largely congruent, but in general with low bootstrap support (Figure 2). The better scores obtained in the Bayesian analysis were expected since unlike the parsimony and distance methods, maximum likelihood and Bayesian inference take full advantage of the information contained in an alignment of DNA sequences when estimating parameters of an evolutionary model (Huelsenbeck and Ronquist, 2005). The high support values obtained in the Bayesian analyses reinforce the findings of Simmons and Miya (2004) that demonstrated that the study of one gene in a large dataset with this kind of method results in a better resolved phylogeny. However, the general interpretation of posterior probabilities obtained with Bayesian analysis has been subject of criticism since higher values are sometimes obtained for low supported branches (Suzuki et al., 2002; Simmons et $a l ., 2004)$, and thus results obtained by this method should be carefully analyzed.

Our results showed that the species of the genus Brycon belong to a monophyletic group (Figure 2) that is well supported, but the genus, as currently defined, is paraphyletic as discussed below. The only topological difference among phylogenetic analytical methods found in the ingroup was the position of $B$. nattereri that could not be resolved with any of the analyses conducted (Figure 2).
Brycon species from the trans-Andean Neotropical region presented some interesting patterns. A well supported clade found in all phylogenetic analysis was composed by $B$. henni, a species occurring in the Rio Magdalena Basin in Colombia, and $B$. petrosus and $B$. chagrensis, two species occurring in the Atlantic coastal river drainages of Panama. Additionally, the species herein identified as $B$. aff. atrocaudatus was recovered as the sister group of all remaining species analyzed in this study, although without strong statistical support. This result is congruent with the hypothesis of Zanata (2000), whereby most species of Brycon from trans-Andean South and Central America form a clade, but more than two lineages exist in the Neotropical region. B. moorei, the remaining transAndean species present in our analysis, was recovered as the sister group to species distributed in the Amazon, São Francisco, and Paraná River Basins, which are discussed below.

Henochilus wheatlandii was recovered among the species of Brycon, as the sister species of $B$. insignis and $B$. ferox, corroborating the monophyly of Bryconinae but rejecting the monophyly of Brycon. In a phylogenetic analysis of the relationships of Brycon and allied genera, Zanata (2000) identified seven morphological synapomorphies that delimited a clade formed by all examined species of Brycon (including B. pesu) along with Chilobrycon, a Brycon-like genus from the western slopes of the Andes (Rio Tumbes basin at the Peruvian-Ecuadorian border; Gé- 
ry and de Rham, 1981). As noticed by Lima (2003) and Castro et al. (2004), Henochilus is morphologically very similar with Brycon and Chilobrycon, however distinct from the latter primarily by the possession of three series of teeth in the premaxillary bone (the generalized condition within Brycon), versus two series of premaxillary teeth in Henochilus. Therefore, the recovery of Henochilus within Brycon in the present analysis, although for the first time proposed, is not really surprising if we consider the fact that Henochilus is the putative sister-group of Chilobrycon (Lima, 2003). The reduction of the number of series of premaxillary teeth may represent an autapomorphy of Henochilus. Consequently, both Chilobrycon and Henochilus are possible synonyms of Brycon. However, we prefer not to synonymize both genera herein and prefer to settle the question in further investigations.

Zanata (2000) found the species Brycon pesu to be the sister species of the remaining Brycon species. In the present study this hypothesis was rejected since $B$. pesu was recovered as the sister species of $B$. opalinus, this clade being sister to other Brycon species found in coastal rivers of South America (B. insignis, B. ferox, and Henochilus wheatlandii), and in the upper Rio Paraná River basin ( $B$. nattereri).

The remaining Brycon species were divided into two clades without strong statistical support. The first clade is composed of the species occurring in the relatively small river basins of eastern Brazil (B. insignis, B. ferox, and $B$. opalinus), plus $B$. nattereri, found in the upper Rio Parana Basin. This result partially corroborates the hypothesis of Zanata (2000) who suggested that $B$. insignis and $B$. opalinus form a monophyletic group, although Zanata (2000) recovered B. nattereri as the sister group of the clade discussed below.

The second Brycon clade is composed by the remaining species of Brycon. The species B. moorei occurring in the Rio Magdalena Basin in trans-Andean South America was recovered as the sister species of the other species. Brycon orbignyanus (La Plata Basin) was recovered as the sister species of $B$. orthotaenia (Rio São Francisco Basin). Brycon hilarii (Rio Paraguay Basin) was recovered as the sister species of $B$. amazonicus. The monophyly of this clade is also well supported morphologically (Zanata, 2000). The presence of B. moore $i$ as the basalmost member of this clade is suggestive of the undoubtedly complex history of the genus Brycon, demonstrating the apparent nonmonophyly of trans-Andean and cis-Andean components of the genus.

The present result points to the fact that Brycon in its present sense is not monophyletic. Further studies including additional species, mainly $B$. falcatus (the type species of the Brycon), as well as Chilobrycon deuterodon, and sequences of different genes coupled with a detailed morphological phylogenetic hypothesis will be necessary for a better understanding of the interrelationships within the species of Brycon, and also to refine the definition of the species in the subfamily Bryconinae.

\section{Acknowledgments}

The authors are grateful to Renata Martins, Marcilene S. Floriano, Érica R. Miguel, Luciana R. Sato, and Kelly T. Abe for their technical assistance, to Dr. Hermes Pineda for loaning samples of Brycon henni, B. amazonicus and B. moorei, and to Dr. Juan Antonio Gomez Herrera for the loan of samples of B. petrosus and B. chagrensis. Funds supporting this study were provided by Fundação de Amparo à Pesquisa do Estado de São Paulo (FAPESP), Conselho Nacional de Desenvolvimento Científico e Tecnológico (CNPq), Universidade Estadual Paulista and the International Foundation for Science (IFS-\#A/3104-1).

\section{References}

Bremer K (1988) The limits of amino acid sequence data in angiosperm phylogenetic reconstruction. Evolution 42:795-803.

Calcagnoto D, Schaefer SA and DeSalle R (2005) Relationships among characiform fishes inferred from analysis of nuclear and mitochondrial gene sequences. Mol Phylogenet Evol 36:135-153.

Carosfeld J, Harvey B, Ross C and Baer A (2003) Migratory fishes of South America: Biology, fisheries and conservation status. World Fisheries Trust, Ottawa, 370 pp.

Castro RMC, Vari RP, Vieira F and Oliveira C (2004) A phylogenetic analysis and redescription of the genus Henochilus (Characiformes, Characidae). Copeia 2004:496-506.

Felsenstein J (1985) Confidence limits on phylogenies: An approach using the bootstrap. Evolution 39:783-791.

Géry J (1977) Characoids of the World. T.F.H. Publications, New Jersey, $672 \mathrm{pp}$.

Géry J and de Rham P (1981) Un nouveau Poisson characidé endémique du bassin du Rio Tumbés au nord dun Pérou, Chilobrycon deuterodon n. g. sp. (Characoidei). Rev Fr Aquariol 8:7-12.

Huelsenbeck JP and Ronquist F (2005) Bayesian analysis of molecular evolution using MrBayes. In: Nielsen R (ed) Statistical Methods in Molecular Evolution. Springer, New York, pp 183-232.

Huelsenbeck JP and Ronquist F (2001) MrBayes: Bayesian inference of phylogeny. Bioinformatics 17:754-755.

Jégu M (2003) Serrasalminae. In: Reis RE, Kullander SO and Ferraris CJ (eds) Check list of the freshwater fishes of South and Central America. EDIPUCRS, Porto Alegre, pp 182196.

Kimura M (1980) A simple method for estimating evolutionary rates of base substitutions through comparative studies of nucleotide sequences. J Mol Evol 16:111-120.

Lima FCT (2003) Subfamily Bryconinae. In: Reis RE, Kullander SO and Ferraris CJ (eds) Check List of the Freshwater Fishes of South and Central America. EDIPUCRS, Porto Alegre, pp 174-181.

Lima FCT (2004) Brycon gouldingi, a new species from the rio Tocantins drainage, Brazil (Ostariophysi, Characiformes, Characidae), with a key to the species in the basin. Ichthyol Expl Freshwaters 15:279-287. 
Lima FCT (2006) Revisão taxonômica e relações filogenéticas do gênero Salminus (Teleostei, Ostariophysi, Characiformes, Characidae). Ph.D. Thesis, Universidade de São Paulo, São Paulo, 253 pp.

Malabarba LR and Weitzman SH (2003) Description of a new genus with six new species from southern Brazil, Uruguay and Argentina, with a discussion of a putative characid clade (Teleostei, Characiformes, Characidae). Comun Mus Ciênc PUCRS, sér Zool 16:67-151.

Palumbi S, Martin A, Romano S, McMillan WO, Stice L and Grabowski G (1991) The Simple Fool's Guide do PCR, v. 2.0. University of Hawaii, Honolulu, $42 \mathrm{pp}$.

Posada D and Crandall KA (1998) Modeltest: Testing the model of DNA substitution. Bioinformatics 14:817-818.

Rodríguez FJ, Oliver JL, Marín A and Medina JR (1990) The general stochastic model of nucleotide substitution. J Theor Biol 142:485-501.

Rosa RS and Lima FCT (2005) Peixes. In: Machado ABM, Martins CS and Drummond GM (eds) Livro da Fauna Brasileira Ameaçada de Extinção. Biodiversitas, Belo Horizonte, pp 67-81.

Salisbury BA (2001) SEPAL - Strongest Evidence and Parsimony AnaLyzer, v. 1.4. Yale University, New Haven. Distributed by the author.

Shimabukuro-Dias CK, Oliveira C, Reis RE and Foresti F (2004) Molecular phylogeny of the armoured catfish family Callichthyidae (Ostariophysi, Siluriformes). Mol Phylogenet Evol 32:152-163.

Simmons MP and Miya M (2004) Efficiently resolving the basal clades of a phylogenetic tree using Bayesian and parsimony approaches: A case study using mitogenomic data from 100 higher teleost fishes. Mol Phylogenet Evol 31:351-362.

Simmons MP, Pickett KM and Miya M (2004) How meaningful are Bayesian support values? Mol Biol Evol 21:188-199.
Suzuki Y, Glazko GV and Nei M (2002) Overcredibility of molecular phylogenies obtained by Bayesian phylogenetics. Proc Natl Acad Sci USA 99:16138-16143.

Swofford DL (2002) PAUP* - Phylogenetic analysis using parsimony (*and other methods), v. 4b10. Sinauer, Sunderland.

Swofford DL, Olsen GJ, Waddell PJ and Hillis DM (1996) Phylogenetic inference. In: Hillis DM, Mable BK and Moritz C (eds) Molecular Systematics. Sinauer, Sunderland, pp 407514.

Taggart JB, Hynes RA, Prodohl PA and Fergusson A (1992) A simplified protocol for routine total DNA isolation from salmonid fishes. J Fish Biol 40:963-965.

Thompson JD, Higgins DG and Gibson TJ (1994) CLUSTAL W: Improving the sensitivity of progressive multiple sequence alignment through sequence weighing, positions-specific gap penalties and weight matrix choice. Nucleic Acids Res 22:4673-4680.

Wasko AP, Martins C, Oliveira C, Senhorini JA and Foresti F (2004) Genetic monitoring of the Amazon fish matrinchã (Brycon cephalus) using RAPD markers: Insights into supportive breeding and conservation programs. J Appl Ichthyol 20:48-52.

Weitzman SH and Malabarba LR (1998) Perspectives about the phylogeny and classification of the Characidae (Teleostei, Characiformes). In: Reis RE, Vari RP, Lucena ZM and Lucena CAS (eds) Phylogeny and Classification of Neotropical Fishes. Edipucrs, Porto Alegre, pp 161-170.

Xia X and Xie Z (2001). DAMBE: Data analysis in molecular biology and evolution. J Heredity 92:371-373.

Zanata AM (2000) Estudo das relações filogenéticas do gênero Brycon Müller and Troschel. Ph.D. Thesis, Universidade de São Paulo, São Paulo, 358 pp.

Zanata AM and Vari RP (2005) The family Alestidae (Ostariophysi, Characiformes): A phylogenetic analysis of a transatlantic clade. Zool J Linn Soc, London 145:1-144.

Associate Editor: Maria Iracilda Sampaio

License information: This is an open-access article distributed under the terms of the Creative Commons Attribution License, which permits unrestricted use, distribution, and reproduction in any medium, provided the original work is properly cited. 